\title{
Anterior choroidal artery infarction
}

\author{
Swaleha Nadaf, ${ }_{1}^{1}$ Rahul T Chakor, ${ }^{2}$ Kaumil Vipul Kothari, ${ }^{1}$ Bhagyadhan A Patel ${ }^{1,2}$
}

${ }^{1}$ Department of Neurology, BYL Nair Charitable Hospital, Mumbai, Maharashtra, India ${ }^{2}$ Department of Neurology, Topiwala National Medical College, Mumbai, Maharashtra, India

\section{Correspondence to} Dr Swaleha Nadaf, ameli786@yahoo.com

Accepted 13 December 2017

\section{DESCRIPTION}

A 38-year-old male patient with a history of hypertension presented with left hemiplegia, hemianaesthesia and hemianopia. MRI of the brain showed anterior choroidal artery (AchA) territory infarct

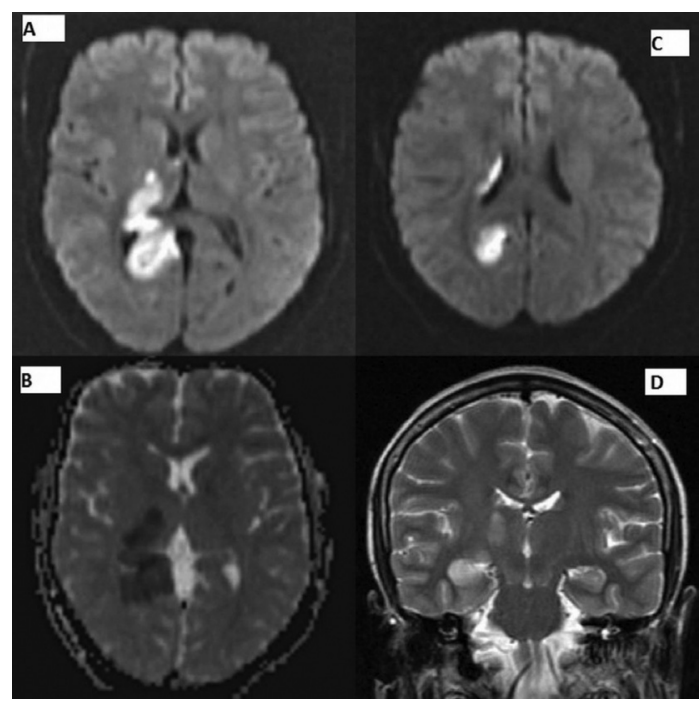

Figure 1 Axial diffusion weighted MRI shows restricted diffusion in $(A, B)$ right lateral thalamus, posterior limb of internal capsule; hippocampal gyrus and uncus and (C) paraventricular corona radiata and uncus. (D) Coronal T2 image showing involvement of same areas. (figure 1). MRI brain angiography and 2D echo were normal. Serum fasting lipid profile, sugar levels, thyroid studies, serum homocysteine levels and antinuclear antibody (ANA), double-stranded deoxyribonucleic acid (DsDNA) and antiphospholipid antibody (APLA) were negative. Trans-oesophageal echocardiography and Holter monitoring were normal. Workup for sickle cell anaemia was negative.

The territory of AchA is shown in figure $2 .{ }^{1}$

The possible clinical presentations of AchA infarcts are as follows:

A. The classic triad (complete)-hemiplegia, hemisensory loss and homonymous hemianopia. $^{2}$

B. Lacunar syndromes.

C. Ataxic hemiparesis.

The patients with AchA infarcts were divided into two groups according to the size of the infarct: large (diameter $\geq 20 \mathrm{~mm}$ ) and small (diameter $<20 \mathrm{~mm}$ ).

Large AchA strokes causing complete triad are rare and are strongly associated with carotid stenosis and cardioembolic sources. Small AchA strokes are responsible for more common lacunar strokes and are usually due to hypertension, diabetes mellitus (DM) and hyperlipidaemia. ${ }^{1}$

Complete triad of hemiplegia, hemianaesthesia and hemianopia with radiological correlation is rare in AchA infarction. This is because of its rich anastomoses with posterior cerebral artery (PCA),
Check for updates

To cite: Nadaf S, Chakor RT, Kothari KV, et al. BMJ Case Rep Published Online First: [please include Day Month Year]. doi:10.1136/bcr-2017222414
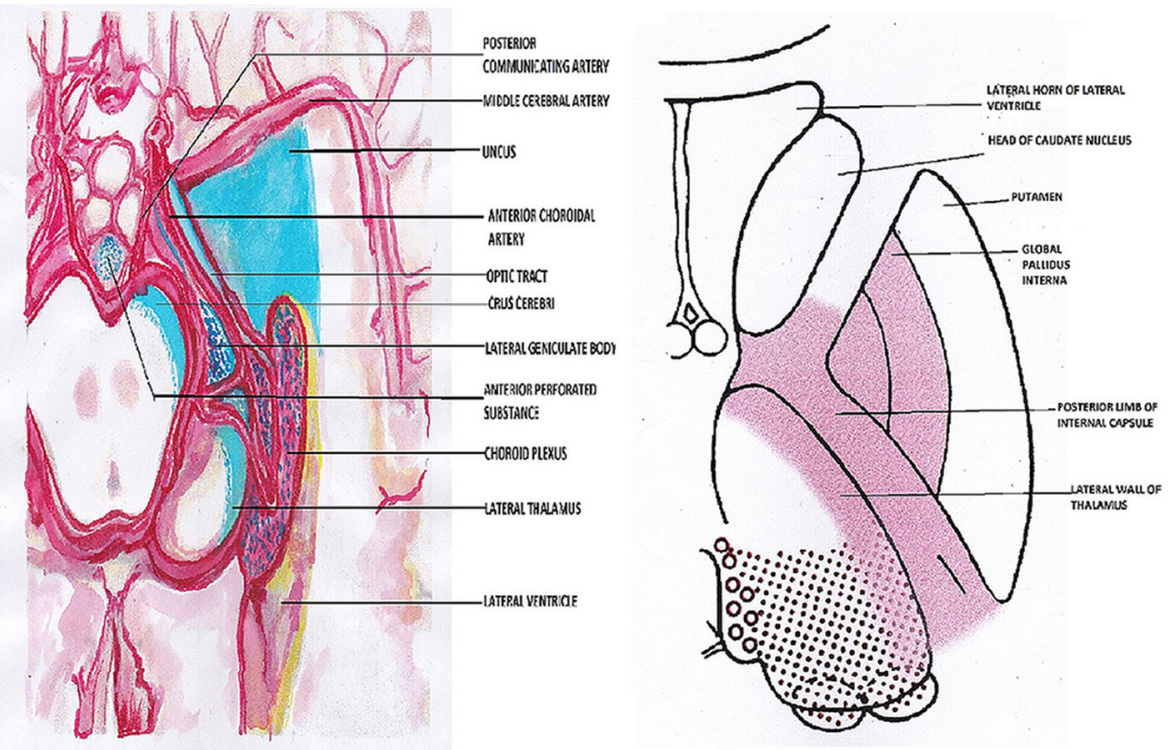

Figure 2 (A) Anterior choroidal artery originates from internal carotid artery (ICA) distal to posterior communicating artery and the cisternal segment supplies the area (blue)—cerebral peduncle, medial temporal lobe, uncus, hippocampus, lateral thalamus, lateral geniculate body, optic radiation, posterior limb of internal capsule, choroidal plexus and paraventricular part of the corona radiata. (B) In basal ganglia, it supplies globus pallidus interna, posterior limb of internal capsule and lateral thalamus areas (pink). 


\section{Learning points}

- When assessing a patient with a triad of hemiplegia, hemianaesthesia and hemianopia, complete anterior choroidal artery (AchA) infarct should be kept in mind.

- The exact extent of AchA infarct should be looked for carefully on imaging in all the sequences and views. As the entire territory cannot be assessed on isolated sections, it has to be traced in multidimensional aspects to determine the exact area of infarct.

- AchA has a very peculiar, strategic territorial distribution. AchA infarction can be deceptive and can be confused with posterior cerebral artery (PCA) or middle cerebral artery-PCA watershed infarction.

posterior communicating artery, posterior choroidal artery and middle cerebral artery (MCA). ${ }^{1}$

The entire territory of AchA infarction cannot be seen on isolated axial or coronal images due to its strategic and extensive area of supply as well as large variations in territorial distribution. It has to be assessed on consecutive slices of MRI or CT in all the sequences such as axial, coronal and sagittal to understand the exact extent of an infarction. Due to its strategic supply, it can be confused with MCA, PCA or MCA-PCA watershed infarct.

Contributors SN: history and examination of the patient, planning concept, conceptualisation, acquisition of data, preparing the manuscript and review of literature. Preparing the images, editing the manuscript and images and preparing learning points. She is the corresponding author. RTC: planning concept, review of literature, analysing and editing the manuscript and analysing the images and editing the learning points. KVK: history taking and examining the patient, helping in editing the manuscript and images and assessing the learning points. BAP: assessing the manuscript and images, helping in preparing learning points and proof-reading.

Competing interests None declared.

Patient consent Obtained.

Provenance and peer review Not commissioned; externally peer reviewed.

(c) BMJ Publishing Group Ltd (unless otherwise stated in the text of the article) 2018. All rights reserved. No commercial use is permitted unless otherwise expressly granted.

\section{REFERENCES}

1 Foix C, Chavany H, Hillemand P, et al. Obliteration de l'artere choroidienne antirieure: ramollissement de son territoire cerebral: h6miplegie, hfmianesthfsie, hfmianopsie (seance du 25 mai). Bull Soc Ophthalmol Fr 1925;37:221-2.

2 Ghika JA, Bogousslavsky J, Regli F. Deep perforators from the carotid system. Template of the vascular territories. Arch Neurol 1990;47:1097-100.

Copyright 2017 BMJ Publishing Group. All rights reserved. For permission to reuse any of this content visit

http://group.bmj.com/group/rights-licensing/permissions.

BMJ Case Report Fellows may re-use this article for personal use and teaching without any further permission.

Become a Fellow of BMJ Case Reports today and you can:

- Submit as many cases as you like

- Enjoy fast sympathetic peer review and rapid publication of accepted articles

- Access all the published articles

Re-use any of the published material for personal use and teaching without further permission

For information on Institutional Fellowships contact consortiasales@bmjgroup.com

Visit casereports.bmj.com for more articles like this and to become a Fellow 